\title{
Analysis on the Cause of Mayang Stream's Mountain Torrent Disaster of the Typhoon Meranti (201614)
}

\author{
Rongyan Zhang', Ge Gao ${ }^{2,3}$, Jinfa Xiao ${ }^{4}$, Xian Wu ${ }^{5}$, Feng Xue ${ }^{1}$, Ruijuan Bao ${ }^{1}$ \\ ${ }^{1}$ Climate Centre of Fujian, Fuzhou, China \\ ${ }^{2}$ National Climate Centre, Beijing, China \\ ${ }^{3}$ Collaborative Innovation Center on Forecast \& Evaluation of Meteorological Disasters, Nanjing University of Information \\ Science \& Technology, Nanjing, China \\ ${ }^{4}$ Changtai Meteorologic Bureau, Changtai, China \\ ${ }^{5}$ Sanming Meteorologic Bureau, Sanming, China \\ Email:fzzry@163.com
}

How to cite this paper: Zhang, R.Y., Gao, G., Xiao, J.F., Wu, X., Xue, F. and Bao, R.J. (2018) Analysis on the Cause of Mayang Stream's Mountain Torrent Disaster of the Typhoon Meranti (201614). Journal of Geoscience and Environment Protection, 6, 87-104. https://doi.org/10.4236/gep.2018.68008

Received: July 4, 2018

Accepted: August 21, 2018

Published: August 24, 2018

Copyright (c) 2018 by authors and Scientific Research Publishing Inc. This work is licensed under the Creative Commons Attribution International License (CC BY 4.0)

http://creativecommons.org/licenses/by/4.0/

c) (i) Open Access

\begin{abstract}
Based on the flood area hydrodynamic model, this paper backs the analysis of the risk warning point of the Mayang Stream in the typical flood process, to determine the disaster-caused critical precipitation and the corresponding flood risk map at different depths of submergence. The result is used as the mountain torrent disaster monitoring and warning indicators and risk assessment of the Mayang Stream. Then based on the flood risk warning service system of small and middle rivers of Fujian Province, the risk warning service of mountain torrent disaster is developed during the impact time of Meranti in 2016. After the process of typhoon, the mountain torrent caused by Meranti was back analyzed by using the decided flood area model, then compared with the results of filed investigation to verify the accuracy of the disaster-caused critical precipitation forecast and the effect of monitoring and early warning services. The result shows that the cause of Mayang Stream's mountain torrent disaster of the typhoon Meranti is the heavy rainfall and the strong wind. The highest mountain torrent disaster was forecasted by the refine precipitation based on the disaster-caused critical rainfall of the Mayang Stream. The simulated flood scenarios and the field trip's results were basically matched in upstream and not matched in the downstream. The post-mountain simulation assessment also showed that the flood inundation range basically matched with reality, but the flood process was biased. The reason was that in addition to the differences between the surface rainfall forecast and the real situation, many actual situations cannot be ignored. For example, Me-
\end{abstract}


ranti caused serious damage to trees, increased river blockages, resulting in changes in flood inundation time and depth, affecting the flood process. It showed the tourism development would cause the river way blocking and increase the risk of flood. In order to prevent and reduce the flood disasters accurately and effectively, the flood risk forecast and the disaster-caused facts should be considered at the same time.

\section{Keywords}

Mayang Stream, Typhoon, Mountain Torrent Disaster, Flood Area

Hydrodynamic Model

\section{Introduction}

China is a mountainous country, and the hilly area covers about two-thirds of the country's land area. It is affected by many factors such as special natural geographical environment, extreme severe weather and economic and social activities. Floods, mudslides and landslides occur frequently in hilly areas, causing casualties, property damage and infrastructure damage, and ecological and environmental damage. Wang Yujie et al. [1] found that the average number of high-temperature days in China increased by 28.4\% from 1961 to 2015, and the number of rainy days increased by $8.2 \%$. Since the 21 st century, the intensity of tropical cyclones landed in China has increased significantly. The frequency and average intensity of tropical cyclones in the surrounding seas of China have shown a weak downward trend in the past 60 years. However, in the past 10 years, the frequency and intensity of tropical cyclones in typhoons and above have increased significantly. The high-risk area of tropical cyclone disasters is located in the northern part of the South China Sea and the eastern part of the Philippine Sea [2]. In the future, China will face more severe climate risk challenges. Liu Zhiyu et al. [3] pointed out that under the background of increasing climate change and human activities, floods and floods are still one of the serious natural disasters in China in the future. The frequency and intensity of extreme flood events in typical flood-risk areas in the south have generally increased. In storms, floods (mountain floods) in the mountainous gullies in the mountains are the main disasters caused by natural disasters in China and have become the focus and difficulty in flood prevention and mitigation in China [4]. Statistics by Zhao Shanshan et al. [5] on the data of China's meteorological disasters from 2004 to 2013 show that storm floods and drought disasters are the most important meteorological disasters in China. The largest number of deaths and direct economic losses is caused by storms and floods. The southeastern coast of China is affected by severe typhoon disasters. Fujian is located on the southeast coast of China and is a typical subtropical monsoon climate zone. Heavy rain can occur throughout the year. However, the short-term heavy rainfall that induced local flash floods was concentrated in April-October, and the April-June was the 
heavy rain in the southern part of China. From July to October, it was typhoon and rain, and the inland areas were dominated by frontal rainstorms. The coastal areas were dominated by typhoon and rain [6] [7]. According to statistics [8], the shortest duration $(3,6$, and 12 hours) of precipitation in Fujian was caused by the typhoon. The short duration of the typhoon storm was significantly stronger than that of the former flood season, and it was more uncertain in the falling season. The storm flood and flood disaster were extremely serious.

In response to the requirements of the World Meteorological Organization (WMO)-based guidelines for multi-hazard forecasting and warning services, the China Meteorological Administration conducted a pilot project in 2011 to transform forecasting of normal weather elements into disaster impact warning services based on the exposure and vulnerability of bearing disasters. It organized five provinces to carry out trials of pilot services and risk assessment services for small and medium-sized rivers, flash floods, and urban flood disasters [9] [10] [11]. Fujian developed a method to determine the critical rainfall for the floods in the absence of hydrological, meteorological and flooding detailed information, and completed the determination of the critical floods for the flood disasters of 78 hills in the province [12]. The "Meteorological Risk Forecast System for Geological Hazards of Floods and Floods in Small and Medium-sized Rivers in Fujian Province" (hereinafter referred to as the "System") has been established to carry out weather warning services for mountain flood disasters. At present, there are few studies on the risk warning of mountain flood disasters and the inspection of service effectiveness. This paper hopes that there will be another severe mountain flooding case that occurred after the typhoon Meranti landing in 2016 affected Fujian and Mayang Stream in Changtai County. A field survey was conducted to compare and analyze the weather risk warning service for mountain torrents based on the achievements of critical floods and the "System" for the prevention of floods, to test the accuracy of the critical rainfall caused by flash floods and the effectiveness of monitoring and early warning services. Further analysis of the causes of the occurrence of rare flash floods in Mayang Stream laid the foundation for improving the capacity of meteorological services for mountain torrents.

\section{Research Area, Data, Ideas and Methods}

\subsection{Basin Overview}

The Mayang Stream River Basin is located in Changtai County, Zhangzhou City, Fujian Province, bordering Xiamen and Longhai (Figure 1). The valley is deep, with a drainage area of 154.5 square kilometers. The length of the main stream is about 32 kilometers, and it eventually flows into the Jiujiang River North Stream. In 2004, the People's Government of Ganzhou City approved the establishment of an eco-tourism area. It is the only one in Ganzhou City in 2010 to win the "Provincial Key Project Construction Excellence Award". It is also a tourist attraction integrating eco-tourism, leisure and vacation, health and fitness, and 


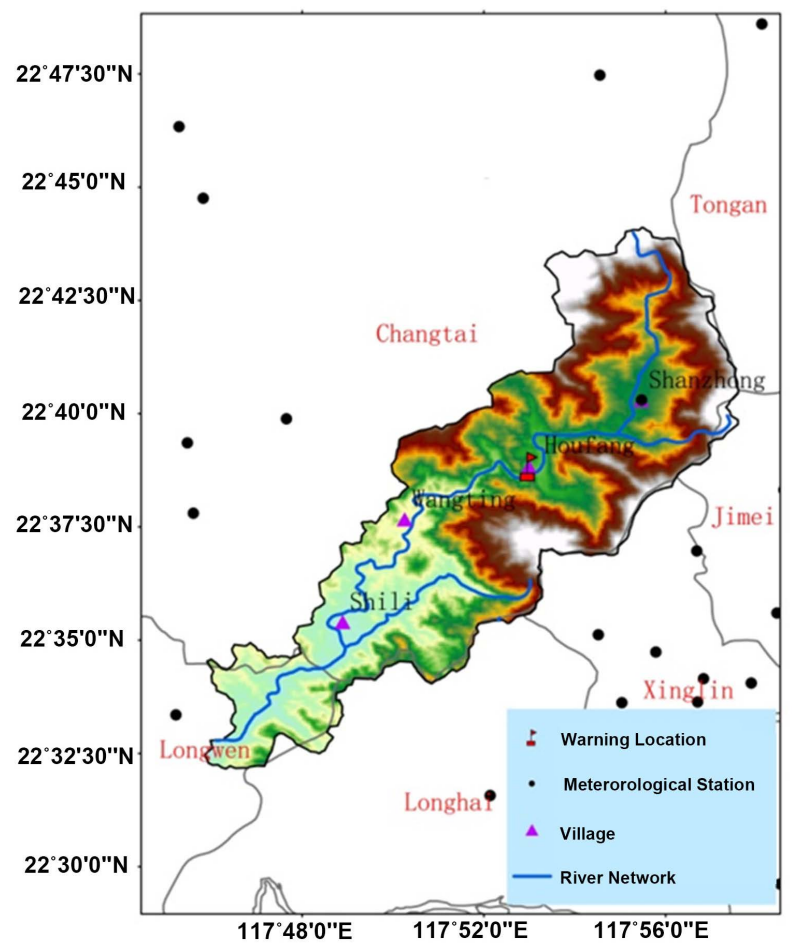

Figure 1. Location of Mayang Stream and distribution of meteorogical observation stations.

cultural expo. The annual tourism revenue exceeds 200 million yuan.

\subsection{Information}

According to the records of mountain flood risk surveys, there were 2 floods in the history of Mayang Stream before 2016, which were the 2006 "Bilis" typhoon process and the 2014 "Hagibis" typhoon process. "Bilis" had not built a regional auto station when it was impacted. It was only possible to determine the storm and storm conditions of the typhoon based on the weather data of the Changtai County weather station. The construction of automatic stations under the influence of "Hagibis" and "Meranti" is becoming more and more perfect. It is possible to understand the spatial distribution of gale and rainfall within the Mayang Stream watershed (Figure 2). The weather conditions of three typhoons are as follows:

Typhoon "Bilis" landed at Xiapu on the northern coast of Fujian at 12:50 on July 14, 2006. Mayang Stream was far away from the center of the typhoon. The maximum instantaneous wind speed at Changtai weather station was only 14.3 $\mathrm{m} / \mathrm{s}$. However, after its landing, it continued to interact with the strong southwest monsoon and formed a strong mechanism for water vapor transport and convergence and rise on the south side of the typhoon. The precipitation on the south side was much stronger than the precipitation on the north side. With abundant water vapor conditions, low-level convergence, high-level divergence, and strong ascending movements, as well as advantageous terrain, Mayang Stream has experienced prolonged periods of heavy precipitation [13] [14] [15] 


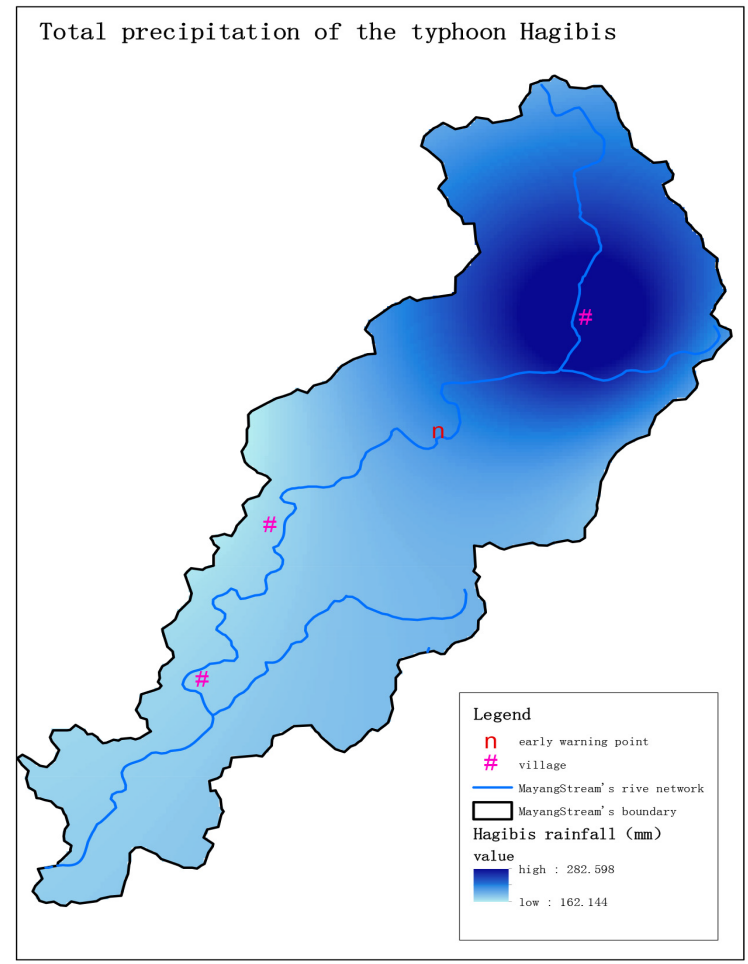

(a)

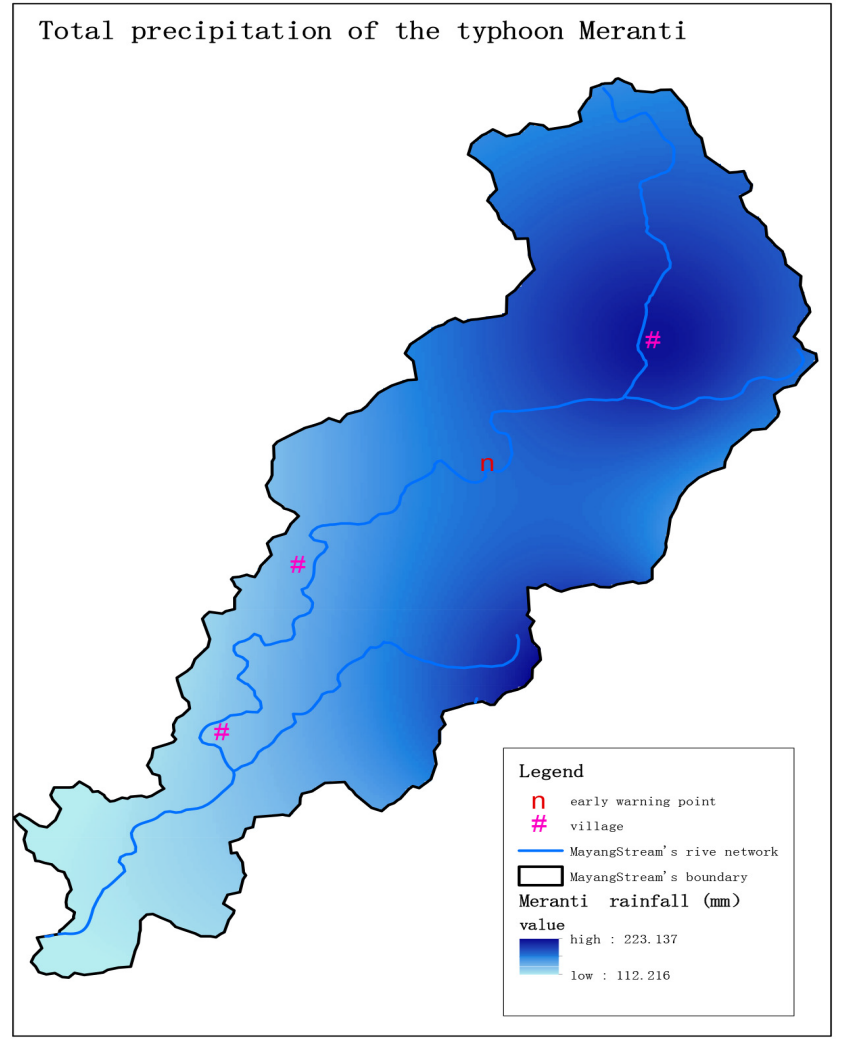

(b)

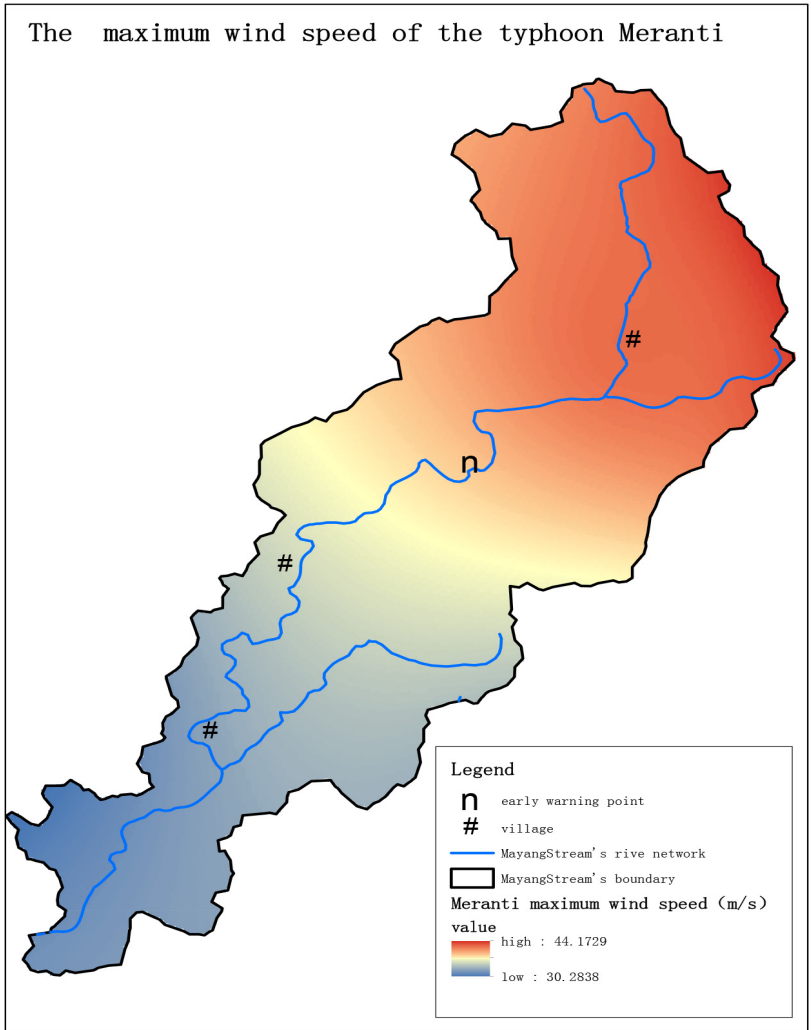

(c)

Figure 2. The spatial distribution of the maximum wind speed and total precipitation of the typhoon Hagibis and Meranti in Mayang Stream. 
[16], triggering the most severe torrential floods. The maximum hourly rainfall at Changtai Weather Station reached $61.8 \mathrm{~mm}$.

Typhoon "Hagibis" landed at Hanjiang District, Shantou City, Guangdong Province at 16:50 on June 15, 2014. After landing, it entered the territory of Fujian Province. The intensity weakened into a tropical depression, and it escalated along the coast of Fujian Province and brought a short period to Mayang Stream. Strong precipitation. According to the analysis of the precipitation observation records of the automatic station in the basin and surrounding areas (Figure 1), the precipitation center is upstream of the basin (Figure 2(a)). The maximum hourly rainfall of the only mountain-heavy automatic station in the basin is $29.1 \mathrm{~mm}$, and the instantaneous wind speed is $10.2 \mathrm{~m} / \mathrm{s}$. At the same time, the instantaneous wind speed of Changtai County Meteorological Station was $14.2 \mathrm{~m} / \mathrm{s}$, which was equivalent to "Bilis"; the maximum hourly rainfall was $25.2 \mathrm{~mm}$, much smaller than "Bilis".

Typhoon "Meranti" No. 14 of 2016 was generated on the northwestern Pacific Ocean at 14:00 on September 10th and became a super typhoon at 1100 hours on the 12th. At 3:05 on the 15th, he landed on the coast of Xiang'an, Xiamen. At the time of landing, the maximum wind force near the center was $15(48 \mathrm{~m} / \mathrm{s}$, strong typhoon level), and the lowest pressure of the center was 945 hectopascals. After crossing the Fujian from south to north, it entered Jiangxi Province on the night of the 15th. From 04:00 to 6:00 on September 15, the typhoon center passed through the northeastern part of Changtai County. The instantaneous wind speed was $43.0 \mathrm{~m} / \mathrm{s}$ (14) in Yanxi Town, Changtai County, and the mountain weight in Mayang Stream River Basin was $42.2 \mathrm{~m} / \mathrm{s}$. Far greater than "Bilis" and "Hagibis", and the largest since 1949 (Figure 2(b)); There was heavy rain in Changtai County and heavy rain in local towns and villages (in Figure 2). The main precipitation period was from 03:00 to 08:00 on the 15th. The maximum hourly rainfall in Shanzhong Village was $46.2 \mathrm{~mm}$, nearly double the "Hagibis". The record of the water level at Houyu Hydro Station in the Shili Village of the lower reaches indicated that at 4 o'clock, when the water reached 5 o'clock, the flood surged nearly $5 \mathrm{~m}$, and the record was then missing. However, the maximum hourly rainfall of Changtai County Meteorological Station is only $19 \mathrm{~mm}$, and the area near the center of the typhoon near the left of the path is extremely narrow.

Comparing the above weather data, it can be seen that "Bilis" has the highest amount of rainfall, but the wind is low; the "Meranti" wind is the strongest, and the rain is not minimal. Both of them are very serious. "Hagibis" has little wind and rain, and relatively small mountain torrents; this is consistent with the current and historical situation of the Morandi torrential field survey in late September 2016.

Field survey data, including the hidden depths, ranges, and times of floods affected by floods during the flood seasons of "Hagibis" and "Meranti", the depth, time, and disaster conditions of the river floods. 
Flood inundation simulation was carried out using 110,000 geographic information provided by the Fujian Basic Geographic Information Center. The data includes watershed boundaries, watershed DEM, water systems, water system ancillary facilities, villages and settlements, buildings, railways, highways, and vegetation (Land use) and so on.

\subsection{Ideas and Methods}

In 2015, when the determination of the critical rainfall of the Mayangxi flash flood was carried out, "Bilis" lacked the automatic station precipitation observation data, and adopted the "Haibeisi" typhoon precipitation case. In 2016, "Meranti" once again affected Mayang Stream, causing severe flash floods. As a result, the identified critical floods were examined and the causes of serious floods were analyzed.

The method for the determination of critical floods and the risk assessment for flood disasters in mountain torrents for the lack of hydrological data was carried out using the study of the chapter of Civilizations [17], combined with the flood investigation data at that time. The main idea is to use the Flood Area hydrodynamic model to invert the flood inundation process caused by the rainfall during the typical flash flood process. According to field investigation of flood hazard information in the basin, the parameters of the model were determined, making the simulated results of each hidden point closer to the inspection results. Using the simulated flood course of the river basin section to determine the critical rainfall at different depths of submerged water, disaster risk assessment of flood-affected areas is carried out based on submerged maps [18] [19]. Due to the remote terrain and lack of hydrological data, most of the methods are of wide applicability. The surface rainfall of the basin was calculated using the regional automatic station built in 2014 and the Thiessen polygon calculation (figure omitted). The Flood Area model [20] was developed for German Geomer Company and integrated seamlessly with ArcGIS in modular form. The principle is a two-dimensional unsteady hydrodynamic model. The calculation is based on hydrodynamic methods.

FloodArea model has three basic simulation modes of flooding scenarios: overcrowding, breaches, and torrential rain. This paper uses storm flooded scenarios to simulate mountain flooding.

\section{Results and Discussion}

\subsection{Critical Threshold for Hazard Determination}

\subsubsection{Determination of Rain-Flood Relationship}

The hourly surface rainfall, digital elevation model (DEM), surface production coefficient, surface hydraulic roughness, and water-blocking structures were taken as input from June 16, 2014 to 00:00 on the 17th. Flood Area was used for flood immersion simulation. The simulation results were compared according to 
the survey data of the warning point (Figure 1). The model parameters were calibrated to extract the flooding depth of the warning points at the time of the best simulation results. Rain-flood relationship analysis was performed on the time-in-depth flood depth and corresponding precipitation (Figure 3 ).

By analyzing the relationship between the simulated flood process line and the accumulated rainfall at Fangfang Bridge at the early warning point, it is found that there is an optimal linear relationship between cumulative precipitation time and flood for 4 hours: $\mathrm{y}=25.928 \mathrm{x}+62.581$, where $\mathrm{x}$ is the depth of the flooding of the warning point and $y$ is the cumulative rainfall of the corresponding submerged water for 4 hours. The correlation coefficient is 0.9501 , passing the 0.01 confidence test.

\subsubsection{Determination of Critical Rainfall for Disasters}

Consider the impact that flood inundation depth may have on people and divide the flash flood disaster into four levels. When Shanhong flood dam (ditch) is a four-level, submerged warning points are 0.6 meters, 1.2 meters, and 1.8 meters are three, two and one level, respectively. Based on the rain-flood relationship, four critical flashes of rainfall intensity were obtained (Table 1).

\section{2. "Meranti” Flash Flood Risk Warning Services}

\subsubsection{Risk Warning}

According to the critical rainfall of the Yangyangshan flood ditches (Table 1) and the future hourly precipitation forecast at 5:00 pm on September 15, 2016, the "System" statistics show that the total amount of surface rain in Mayang Stream that will accumulate for more than 4 hours in the future will surpass the standard for grade 1 floods and issue severe mountain flood warning signals and short messages. "System" rolling live rainfall display: At 4:20, the system scrolled for 4 hours in real time. The rainfall reached the 4 th level flash flood indicator. At 5:00, it reached the 2nd level flash flood indicator. After 50 minutes, it reached the 1st level indicator. The corresponding level of the flash flood warning message was issued. At the same time, the system automatically retrieves the corresponding level of flood immersion maps (Figure 4) and submerged hidden point depth information (Table 2), according to the short-term warning of 5:00 am on the 15th, the next 4 hours (live + forecast), the accumulated rainfall reaches $111 \mathrm{~mm}$, It is estimated that Houfang Village may be submerged in water depth of more than 3 meters, and the downstream areas will be flooded by floods and floods.

\subsubsection{Service Situation}

The "System" automatically publishes flash flood warnings and live alarm messages, which are quickly sent to the responsible persons of the meteorological departments at all levels. Changtai County Meteorological Bureau of the Disaster Prevention and Mitigation Implementation Department, based on real-time flash flood monitoring and early warning landing and direct landing of flood 


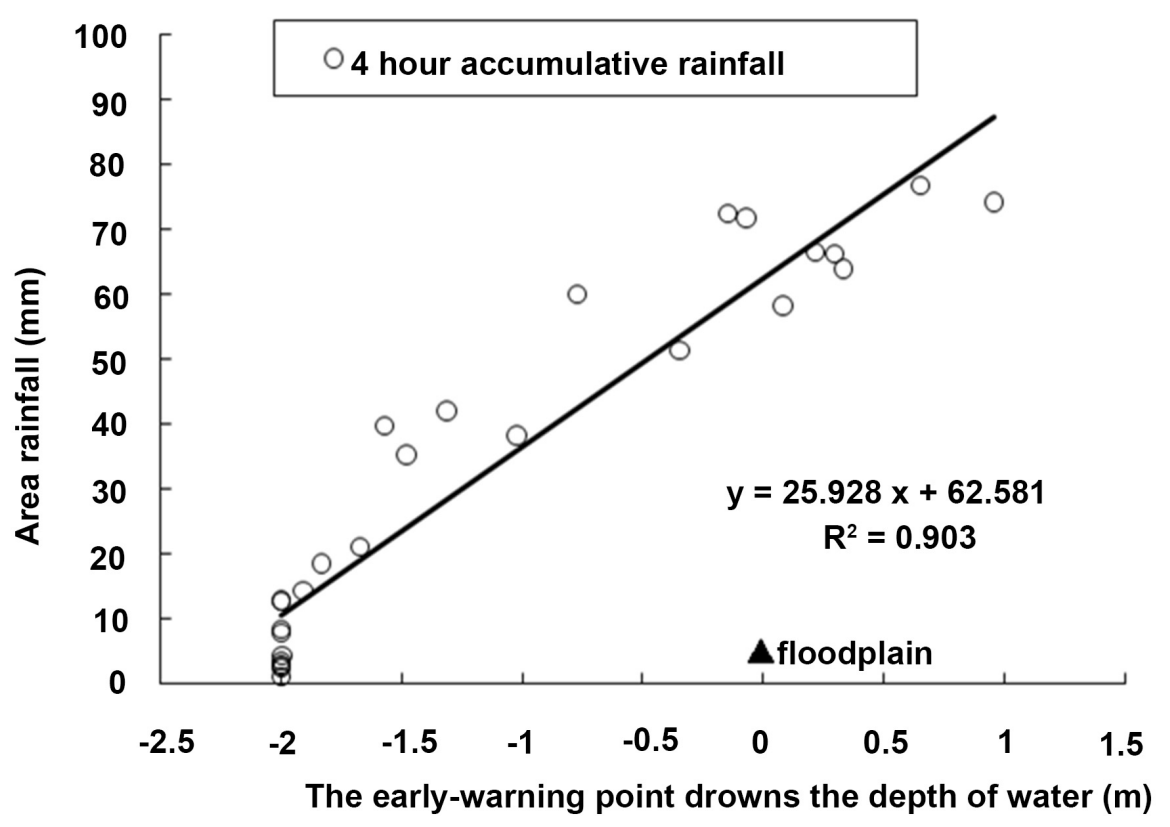

Figure 3. The relation between heavy rain and flood in Mayang Stream.

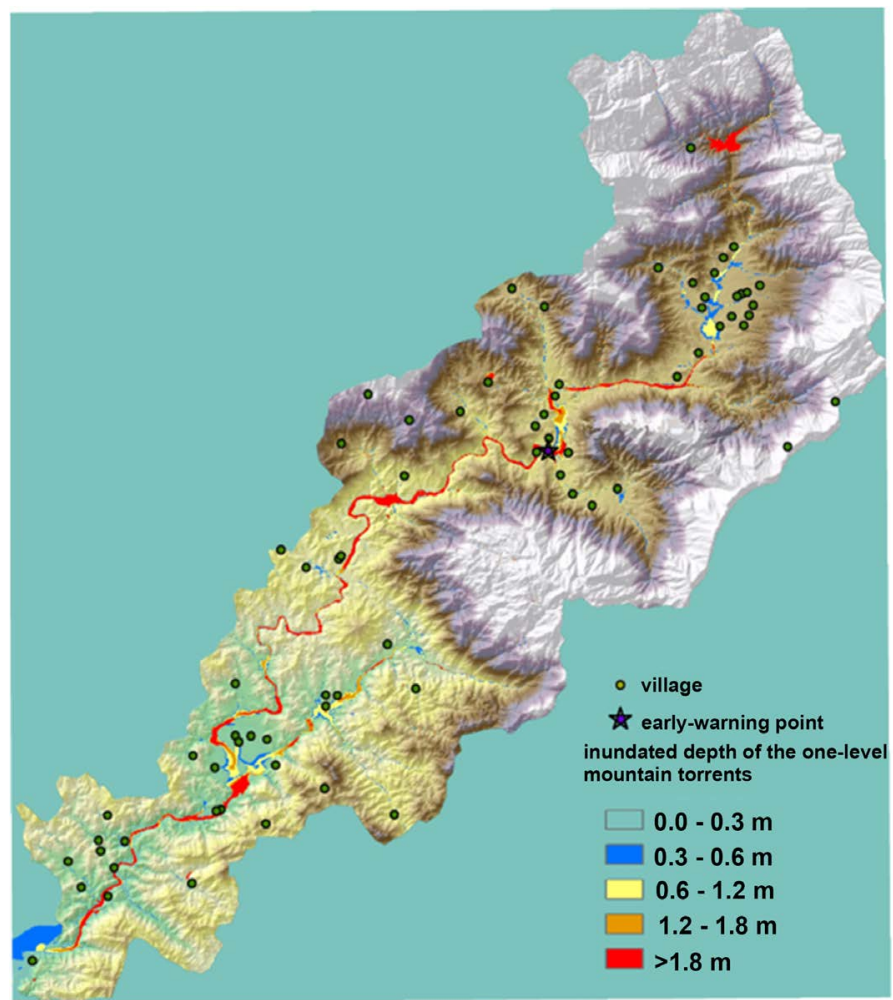

Figure 4. The flood risk map of the one-level mountain torrents.

disasters in southern Yunnan type flood disaster area results [21]. Report the "Important Weather Warning Report" to relevant local decision-making agencies such as the county party committee, the county government, and the Flood Control Office, and start the highest level of typhoon defense measures. 
Table 1. The classification of the disaster-caused critical rainfall in Mayang Stream.

\begin{tabular}{ccccc}
\hline Torrent Level & $\begin{array}{c}\text { Alert Point } \\
\text { Name }\end{array}$ & $\begin{array}{c}\text { Submerged Depth } \\
(\mathrm{m})\end{array}$ & $\begin{array}{c}\text { Critical Rainfall } \\
(\mathrm{mm})\end{array}$ & Cumulative aging \\
\hline Level 4 & & 0 & 62.6 & \\
Level 3 & Houfang Village & 0.6 & 78.1 & 4 hours \\
Level 2 & & 1.2 & 93.7 & \\
Level 1 & & 1.8 & 109.3 & \\
\hline
\end{tabular}

Table 2. The flood depth of the one-level mountain torrents at Mayang Stream's potential points.

\begin{tabular}{cccc}
\hline Submerged Location & $\begin{array}{c}\text { Level 1 Flood May } \\
\text { Inundate the Depth of } \\
\text { the Village }(\mathrm{m})\end{array}$ & $\begin{array}{c}\text { Level 1 Flood Critical } \\
\text { Tainfall }\end{array}$ & $\begin{array}{c}\text { Forecast } 4 \text { hours of } \\
\text { Accumulated Rainfall }\end{array}$ \\
\hline $\begin{array}{c}\text { Mountain Heavy Field } \\
\text { Houfang Village Mawei } \\
\text { Natural Village }\end{array}$ & 0.75 & & \\
Houfang Bridge & 2.09 & $109.3 \mathrm{~mm}$ & $>111 \mathrm{~mm}$ \\
Shili Primary School & 2.82 & & \\
Near the River Coast & 1.62 & & \\
\hline
\end{tabular}

The use of telephone, fax, SMS, television, weather information platform, microblogging, LED display screens and other platforms to release typhoon news to the public.

\subsection{Flood Investigations}

Red Rock Reservoir upstream of Mayang Stream, on the 14th, the water level was 277.2 meters (before the typhoon storm occurred). On the 15th, the water level at 5:30 was 288.4 meters, which exceeded the elevation of the bottom of the spillway. At 6 o'clock, the water level reached its highest level $(290.4 \mathrm{~m})$. At 8 o'clock, the water level dropped back to $289.8 \mathrm{~m}$. The reservoir overflowed naturally and the reservoir level returned to normal on the 21st. There are four villages along the river basin: the village of Shangzhong in the upper reaches, Houfang Village and Wangting Village in the middle reaches, and Shili Village in the lower reaches (Figure 1). Flooding occurred in the basin at 3 to 6 o'clock on the 15 th, and the deepest submergence occurred around 4 o'clock. During the middle and upper reaches of the time of water withdrawal, 5 to 6 o'clock, about 10 o'clock in the downstream, 1 to 2 hours of flood retreat is completed, which is a typical storm surge.

In the upstream area, fierce flash floods scour the surface, trees fall down, and culverts are blocked, resulting in road collapse. The heavy flood of the bridge over the river exceeds 2.3 meters and floods about 50 meters on both sides of the river. In the middle reaches of the area (the back square), the floods entrained a large number of weeds in the trees and blocked the Maju Bridge hole. The water 
depth of the river was 8.7 meters, and the flood bridge was 0.65 meters. The two piers along the coast were hollowed out. This is the largest flood in 48 years since the bridge was built in 1968 (Figure 5, left). It inundates and destroys a large number of agricultural facilities. The ecological orchard turns into a rocky beach. The downstream Shili Village is more flooding, and the bridge guardrails are flushed or washed away (Figure 5). The Longfeng Valley Scenic Spot and Xiaguang Rafting Company are all soaked in water that is more than 2 meters deep (Figure 5, right).

\section{4. "Meranti" Flash Flood Inversion}

After the end of the process, according to the actual rainfall, the Tyson polygon is used to calculate the hourly watershed surface rainfall, which drives the Flood Area model with a predetermined threshold value, and inverts the flood course of the actual flash flood process and the early warning point section of Meranti (Figure 6(a)).

\subsection{Disaster Critical Threshold Test}

The amount of live rainfall is used to check the flood level of the warning point and the flood warning time of all levels, as well as the aging of the accumulated rainfall and the flooding depth and time of the warning point.

It can be seen from the change of the cumulative surface rainfall on Figure 6(a) (histogram). The cumulative surface rainfall at 4 to 8 hours is close to or exceeds the critical threshold of the 1st mountain flash $(109.3 \mathrm{~mm})$, indicating that the water depth of the flood flooding warning point is more than 1.8 meters. The in-situ measurement and early warning point is submerged with a water depth of about 3 meters, which belongs to the first-level mountain flood, indicating that the critical rainfall indicates that the flash flood level and the maximum flooding depth of the warning point are correct.

Through the relationship between the hourly water depth and cumulative hourly rainfall of the Meranti warning point, the best correlation is between 4 and 5 hours, with a correlation coefficient of 0.91 to 0.94 and a confidence level
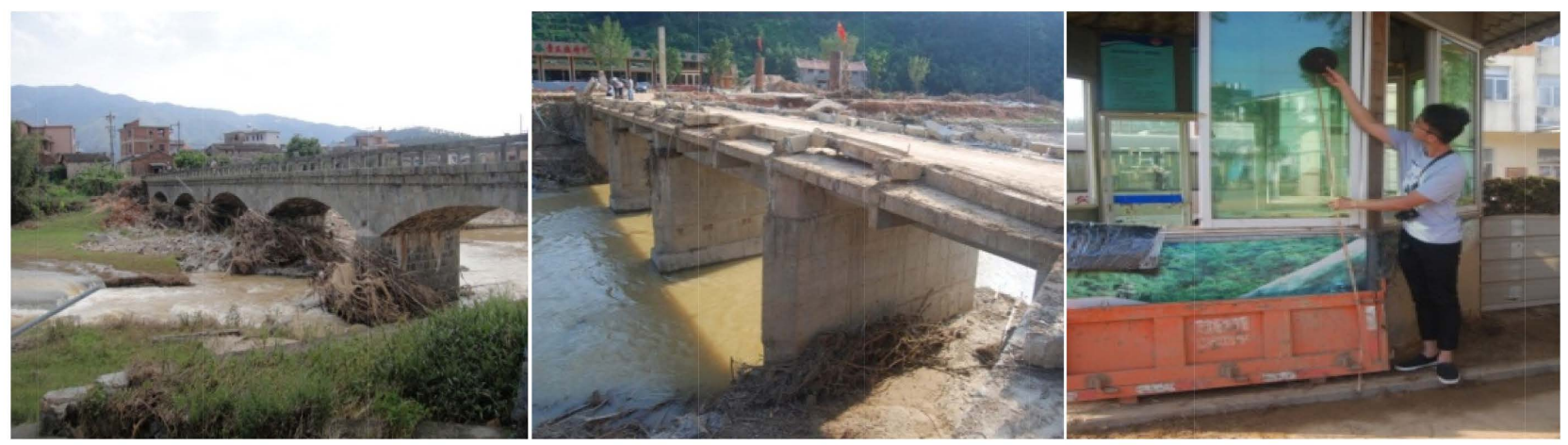

Figure 5. The river way of Macuo Village (left), the destroyed Bridge of Longfenggu (middle), the service center of Xiaguang drifting company (right). 


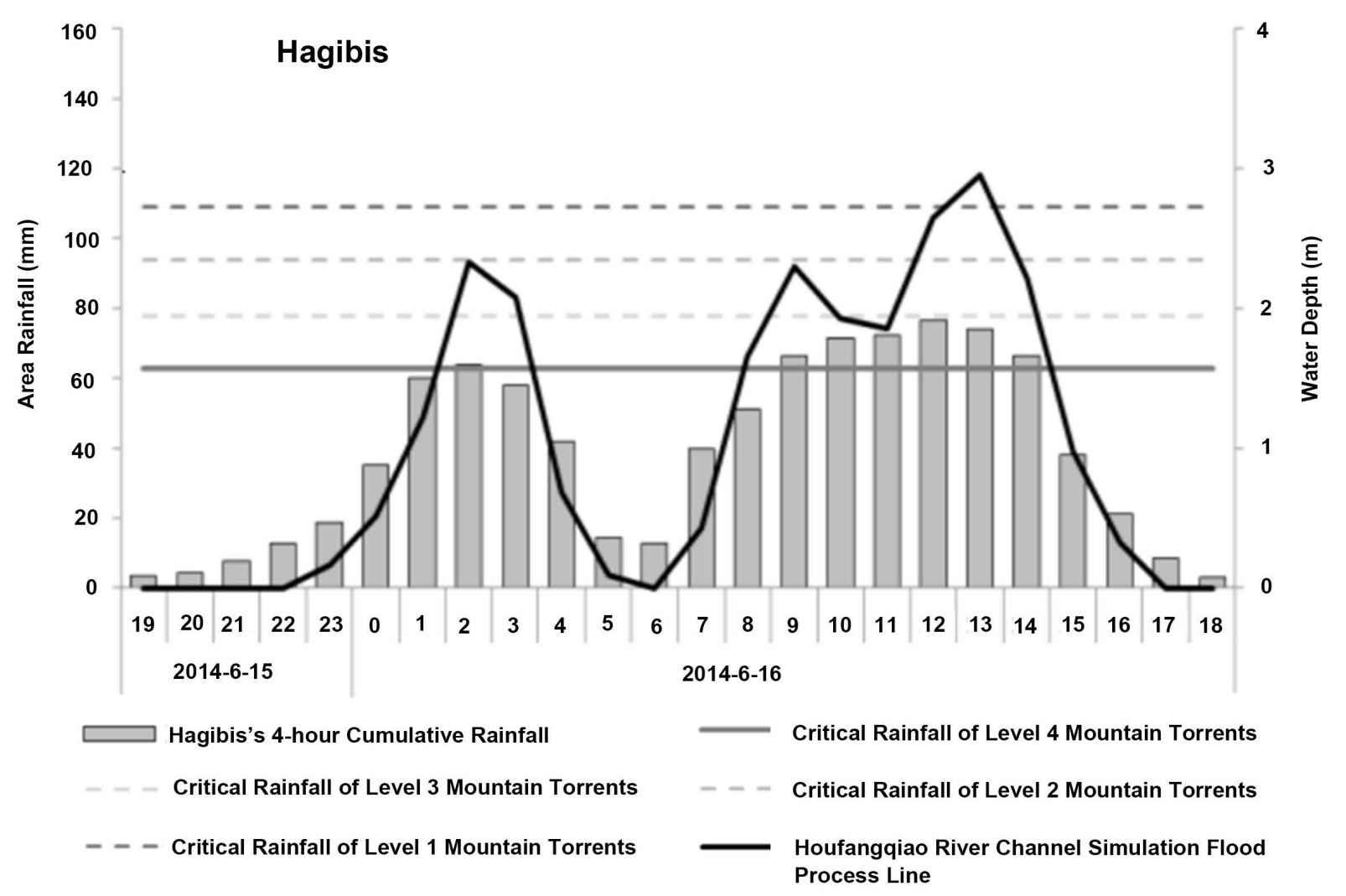

(a)

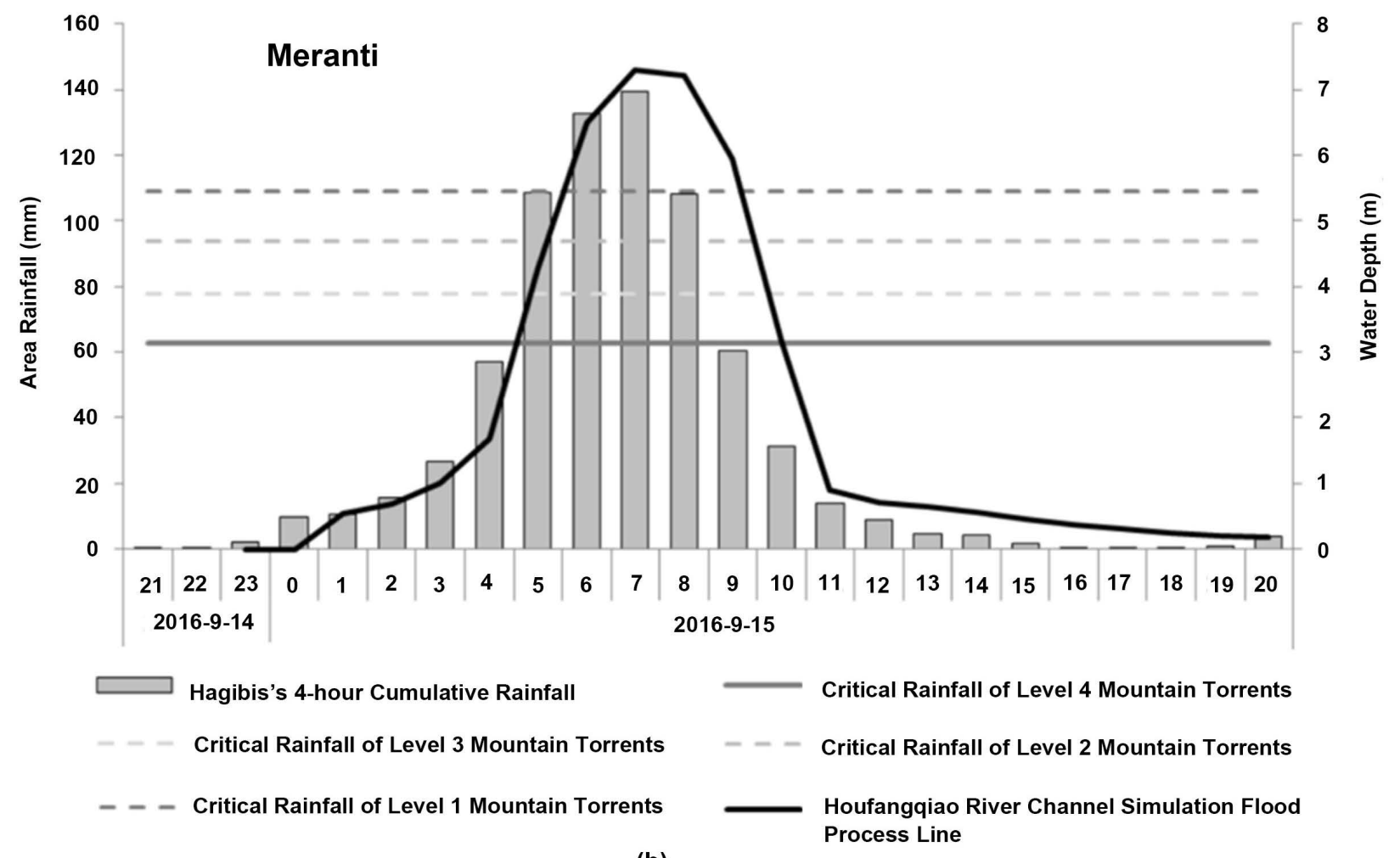

(b)

Figure 6. Analysis of the disaster-caused meteorological facters of the typhoon Meranti (a) and Hagibis (b). 
of 0.01 . It shows that the cumulative time length of the critical rainfall caused by the "Hagibis" precipitation process is reasonable.

According to the flood warnings described by the villagers, the flood situation is "more than 3 hours of water, and soon flooded the coast. At 5 o'clock, the water level is the highest". From the results of the live monitoring, the threshold indicates that it has not been submerged at 4 o'clock (Figure 6 left), which is 1 to 2 hours behind the description. Analyze the causes of the error and find that "Hagibis", which determines the critical rainfall for the disaster, is an early typhoon rainfall during the rainy season. The hourly rainfall changes are bimodal and heavy (Figure 6 right), while "Meranti" belongs to a pure typhoon; the hourly rainfall was single-peak and thin (Figure 6 left). Although the spatial distribution of the process rainfall is very similar between the two, the precipitation center is in the upper reaches of the river basin (Figure 2(a), Figure 2(b)), but the cumulative hourly rainfall (induced flood/rainfall) peak value of "Meranti" is twice as high as that of "Hagibis"; and with the duration of 3 to 4 hours, the rain intensity difference, the flood rose faster.

From the short-term forecast results, the "strongest" flash flood warning signal automatically issued by the "system" is 5 , the time is consistent with the actual maximum flood, and the short-term warning effect cannot be achieved. After the completion of the process, the WRF forecasting product of the anti-surveillance system shows that the 3 -hour forecasted cumulative rainfall at the river basin, which is close to the cumulative aging time of the critical precipitation at Mayang Stream, reached level 4 warning at 1 o'clock on the 15 th, and immediately upgraded to the level 1 warning at 2 o'clock and continued to 6 o'clock. All of them are high-risk warnings of mountain floods above Grade 2 and indicate that the WRF product warnings are quite effective and can alert high-risk flash floods 3 hours in advance. It can be seen that the "system" needs to be further improved, and full use of forecast information, while improving the accuracy of precipitation forecasts, will have enough time to prevent floods and reduce unnecessary loss of tourist attractions.

\subsection{Submerged Inspection}

The Mayang Stream's FloodArea hydrodynamic model was used to simulate the actual precipitation process of "Meranti", and the flooding time, maximum submergence range and deepest submergence depth of important hidden danger points in the whole river basin were tested.

\subsubsection{Maximum Flood Depth and Range Inspection}

Take the "Meranti" flood inversion process to inundate the depth map, and read the water depth of the hidden point: the deepest water depth of the Majuqiao River is 8 meters, the depth of the Houfang Bridge is 7.2 meters, and the warning point is submerged to a depth of 3 meters. The water depth at the Maju Bridge at the site was 8.7 meters, the water depth at the Houfang Bridge was over 6.6 me- 
ters, and the water depth at the warning point was close to 2.82 meters. In the Maji Bridge, Houfang Bridge and Longfeng Valley, the flood submerged boundary was measured. The inundation width of the Maji Bridge was about 40 meters, the width of the Houfang Village Bridge was about 250 meters, and the Longfeng Valley was nearly 70 meters. Similar to the results of the simulation in Figure 7. The results of the inspection of the depth and extent of submergence of individual hidden watersheds in the river basin show that the hydrodynamic model developed using the "Hagibis" rainfall can be used to express the scope and depth of flooding in Mayang Stream, and has certain ability to evaluate the damage degree of Mayang Stream flood.

\subsubsection{Inundation Time Test}

From the results of the time-lapse simulation of the flash flood process, the flood is piled up downstream in a stepwise manner (figure omitted). The comparison of the simulations and surveys of each village can be seen (Table 3). There is a difference between the two, and this difference is particularly significant in the downstream. Through field investigations, it was found that when the flood occurred, multiple bridge holes on the river channel were severely blocked. The temporary construction of the "damper lake" leads to poor flood discharge. As the flood pressure increases, it will be hollowed out and suddenly leaked, thus changing the flood process. This may be the main reason for the difference between the actual situation and the simulation results.

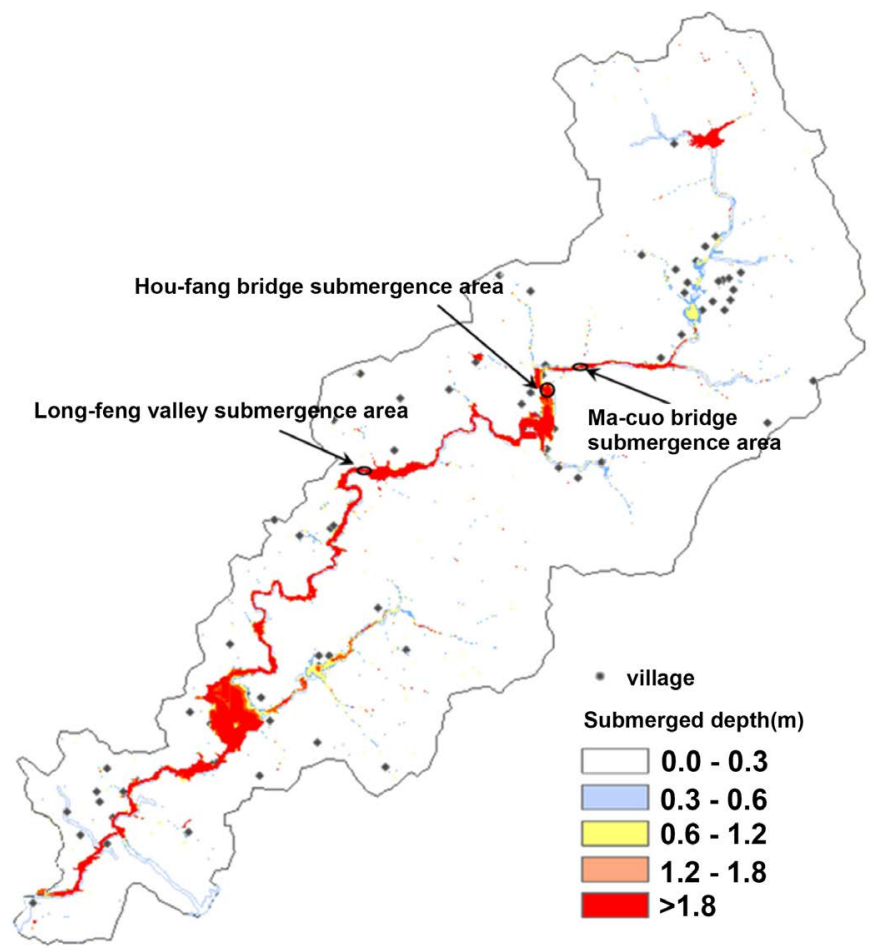

Figure 7. The deepest flood risk map of the mountain torrents during the typhoon Meranti in Mayang Stream. 
Table 3. The comparison between the simulated flood scenarios and the field trip's results during the typhoon.

\begin{tabular}{|c|c|c|c|c|c|c|c|c|}
\hline \multirow{2}{*}{$\begin{array}{c}\text { Hidden } \\
\text { Point }\end{array}$} & \multicolumn{3}{|c|}{ Simulation Result } & \multicolumn{3}{|c|}{ Fieldwork Results } & \multirow[b]{2}{*}{ Time Test } & \multirow[b]{2}{*}{ Range Test } \\
\hline & $\begin{array}{l}\text { Rise } \\
\text { Time }\end{array}$ & $\begin{array}{c}\text { Deepest } \\
\text { Time }\end{array}$ & $\begin{array}{c}\text { Recession } \\
\text { Time }\end{array}$ & $\begin{array}{l}\text { Rise } \\
\text { Time }\end{array}$ & $\begin{array}{c}\text { Deepest } \\
\text { Time }\end{array}$ & $\begin{array}{c}\text { Recession } \\
\text { Time }\end{array}$ & & \\
\hline $\begin{array}{c}\text { Mountain } \\
\text { village }\end{array}$ & $4: 00$ & $6: 00$ & $7: 00$ & $4: 00$ & $5: 00$ & 1 & Near & Near \\
\hline $\begin{array}{l}\text { Houfang } \\
\text { Village }\end{array}$ & $4: 00$ & $7: 00$ & $8: 00$ & $4: 00$ & $5: 00$ & 1 & Near & Near \\
\hline $\begin{array}{l}\text { Wangting } \\
\text { Village }\end{array}$ & $4: 00$ & $13: 00-14: 00$ & 15:00 & $4: 00$ & $5: 00$ & 1 & Differences & Near \\
\hline Shili Village & $5: 00$ & 11:00-16:00 & $16: 00$ & $5: 00$ & 8:00 & 3 & Differences & Differences \\
\hline
\end{tabular}

\subsection{Causes of Disasters}

The height of flood in Houfang Village has reached the highest level in the past 40 years. It is understood that the typhoon process rainfall of "Meranti" did not exceed the "Bilis" typhoon that caused severe floods in 2006. Why did the flood water depth exceed the historical record? In order to find out the reasons, the differences between the "Bilis" and "Meranti" were analyzed.

Due to the absence of rainfall records during the impact of the "Bilis" period, a statistical comparison of the hourly rainfall during the impact of two typhoons at the Changtai meteorological station near the lower reaches of the river basin (Figure 8) confirms that the "Bilis" rainfall intensity far exceeds that of "Meranti". However, the instantaneous wind speed "Meranti" is as high as $31.7 \mathrm{~m} / \mathrm{s}$, far more than the "Bilis" $17.4 \mathrm{~m} / \mathrm{s}$. When the typhoon passes through the north of the basin, that is, the upstream area, it is the center of the wind, and the intensity is still strong. Figure 2(b)). Actual investigations by "Meranti" found that before the typhoon process, the river was cleared according to flood prevention preparation requirements, but during the typhoon process. Due to the large winds, the trees in the river basin were laid down or broken by strong winds, and the broken branches were brought together into the river. With the debris, sand, rocks, and rubbish washed off by the flood, the bridge was blocked and the water flow was poor, causing the flood water to rise and spread. The bridge served as a short-term "barrier lake" dam, and the bridge was heavily flooded nearby.

In addition, since the development of MayangStream's tourist area in 2006 was only two years, after more than 10 years of construction and development of scenic spots, some tourist facilities, farmhouses, and ecological orchards have gradually gathered on the river. This will seriously affect the flood discharge of the river. Once the flood occurs, it will also cause great economic losses and become a hidden point of danger. Flood risk is high.

\section{Conclusions}

Typhoon "Meranti" is the strongest typhoon affecting Changtai County since 1949. It is rare for history, and the duration of strong winds is long and destructive. 


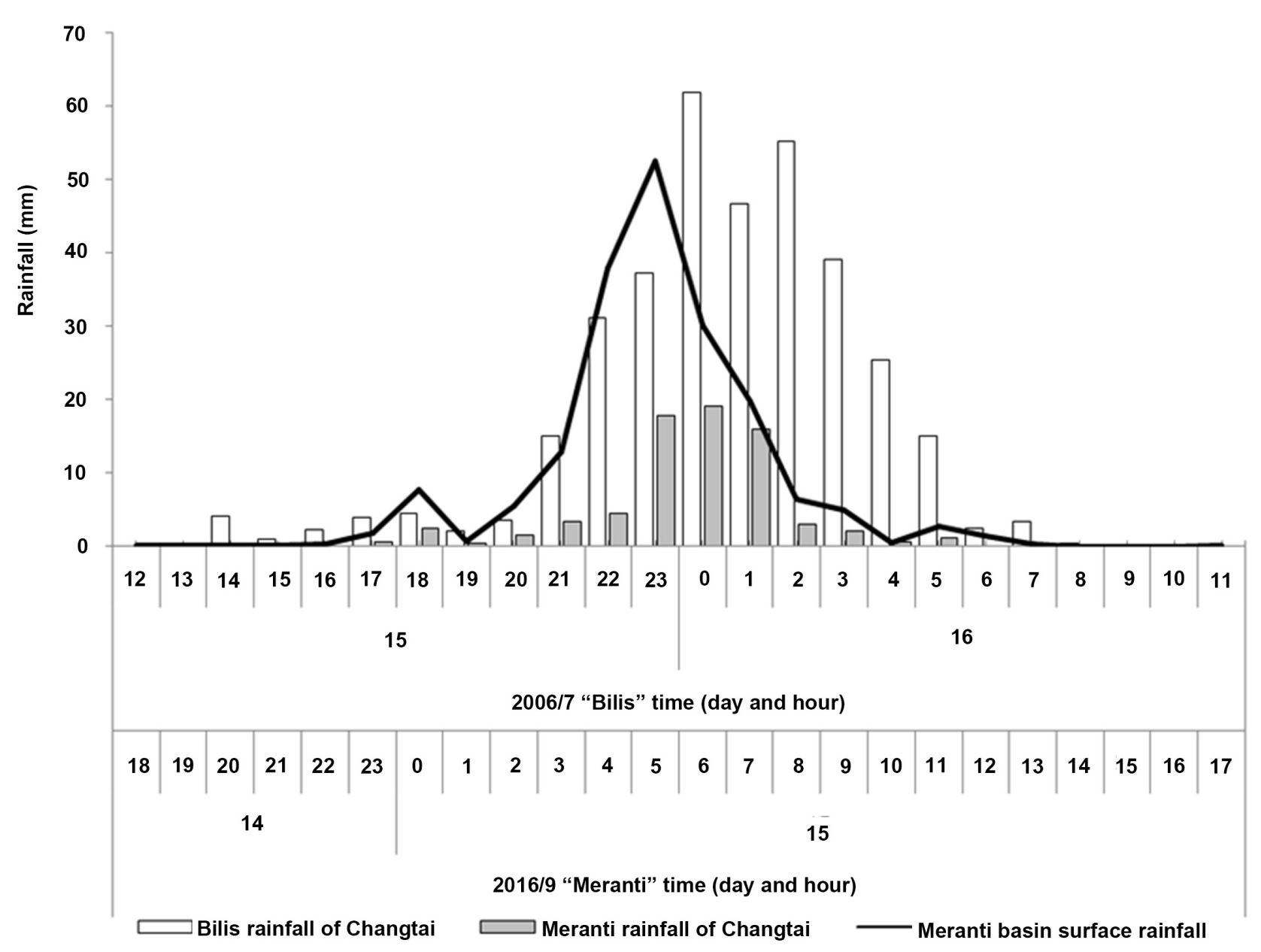

Figure 8. The comparison of hourly precipitation between the typhoon Meranti and Bilis.

The precipitation forecast of the Fujian Provincial Meteorological Observatory issued a 4-hour ahead of schedule for the risk of severe flash floods in Mayang Stream. Leaders of Changtai County government attached great importance to the work of preventing Taiwan and resisting Taiwan. In the County Flood Control and Drought Relief Headquarters, a number of anti-Taiwan and anti-Taiwan work conferences were held. The relevant departments and townships (countries and districts) of the county directly strengthened their alliances and made in-depth measures to prevent damages caused by disasters to a minimum. According to incomplete statistics, the direct economic loss caused by this process was 214 million yuan, and 2 people died.

Through detailed analysis of the case, it can be seen that using the critical rainfall indicator and the fine precipitation forecast to monitor the flash flood has obvious early aging and disaster prevention and mitigation significance. Based on the critical floods developed by the "Hagibis" process, it is equally effective for the "Meranti" flash flood warning. The Critical Rainfall Assessment of Disasters indicates that the fine precipitation forecast products can issue high-level flash flood warnings within 3 hours in advance. The maximum sub- 
merged depth of flash floods and warning points in the river basin is consistent with the actual situation, but the prompt occurrence of high-level flash floods lags behind. The error is caused by different precipitation scenarios. Flood Area simulations simulating the Meranti flood, the flooded area, submerged timeline and water depth in the upper and middle reaches are close to reality, and the downstream is poor. Therefore, it is necessary to improve the hydrodynamic model so that it can adapt to different rainfall scenarios, different segmented water blocking scenarios, and flood simulations of different underlying surface conditions. In addition, there is need to prepare corresponding risk warning indicators and assessment maps in advance to deal with the sudden and escalation of mountain torrents in different scenarios to gain time for disaster prevention and reduction.

Through investigation and analysis, how to guarantee the smooth flow of rivers during floods is a problem that we urgently need to solve, and avoid the temporary impoundment and the sudden release of flood water that causes greater harm. According to the lessons learned from loss, tourism infrastructure, housing construction, and economic orchards should be built outside the potentially flood prone areas and away from the river, thus reducing risks.

\section{Acknowledgements}

This work was supported by National Natural Science Foundation (41575052), Fujian Meteorological Bureau Open Meteorological Research Fund Project (2014K03), China Meteorological Administration Climate Change Special (CCSF201712) and Meteorological Support Project for Mountain Flood Geological Disaster Prevention and Control of China Meteorological Administration. This article has received strong support and help from the Zhangzhou Meteorological Bureau, Changtai County Meteorological Bureau and Changtai County Flood Control Office. I would like to express my heartfelt thanks!

\section{Conflicts of Interest}

The authors declare no conflicts of interest regarding the publication of this paper.

\section{References}

[1] Wang, Y.J., Zhou, B.T., Ren, Y.Y., et al. (2016) Reflections on the Impact of Global Climate Change on China's Climate Security. Applied Meteorological Journal, 27, 750-758.

[2] Li, Q., Zhang, R., Yao, X.F., et al. (2013) Risk Assessment and Regionalization of Tropical Cyclone Disasters in Peripheral Waters of China under the Background of Climate Change. Journal of Tropical Meteorology, 29, 143-148.

[3] Liu, Z.Y. and Xia, J. (2016) Impact of Climate Change on Flood Disaster Risk in China. Natural Journal, 39, 177-181.

[4] China Mountain Flood Prevention Network (2012) Overview of Mountain Flood Disaster Prevention and Control Projects: Progress of Prevention and Control of 
Mountain Flood Disasters in China. http://www.qgshzh.com/

[5] Zhao, S.S., Gao, G., Huang, D.P., et al. (2017) Analysis on the Characteristics of China's Meteorological Disaster Losses from 2004 to 2013. Journal of Meteorology and Environment, 33, 101-107.

[6] Lu, S.J. and Wang, Y. (2012) Fujian Climate. Meteorology Press, Beijing, 520.

[7] Fujian Provincial Agricultural Division Committee Office (1990) Fujian Agricultural Climate Resources and Regional Planning. Fujian Science and Technology Press, Fuzhou, 181.

[8] Wu, B., Wen, M.Z., Li, L., et al. (2015) Spatial and Temporal Distribution of Heavy Rainfall over Different Short Durations in Fujian Province. Rainstorm, 34, 1-6.

[9] Zhou, Y.H., Tian, H., Li, L., et al. (2015) Heavy Rain Induced Flood Risk Warning Service Business Technical Guide. Meteorology Press, Beijing, 65.

[10] Zhang, R.Y., Zhang, G.C., Zhang, Y., et al. (2015) Heavy Rain-Induced Flash Flood Risk Warning Service Business Technical Guide. Meteorology Press, Beijing, 57.

[11] Li, C.M., Tang, L.S. and Zhang, G.C. (2015) Technology Guide for Risk Warning Services in Cities. Meteorology Press, Beijing, 40.

[12] Zhang, G.C., et al. (2012) Storm Flood Forecasting and Risk Assessment. Meteorology Press, Beijing, 156.

[13] Yu, Z.S., Chen, M., Ye, Z.X., et al. (2009) Comparative Analysis of Tropical Cyclone "Haicang" (0505) and "Bilis" (0604) Heavy Rain. Journal of Tropical Meteorology, 24, 37-47.

[14] Luo, L., Lou, X.F., Hu, L., et al. (2013) The Structural Characteristics of the Strong Tropical Storm "Bilis" 0604 and the Cause of Heavy Rain. Meteorological Science, 33, 208-214.

[15] Yin, J., Wang, H. and Chen, J.P. (2008) Analysis of the Causes of Sustained Heavy Rain in South China Caused by Strong Tropical Storm Bilis. Meteorological Technology, 36, 63-68.

[16] Dong, M.Y., Chen, L.S., Zhen, P.Q., et al. (2009) Research Progress on the Sudden Increase of Tropical Cyclone Rainfall and Heavy Rainstorm Landing. Journal of Tropical Meteorology, 25, 495-502.

[17] Wen, M.Z., Lin, X., You, L.J., et al. (2013) Research on Risk Assessment Method of Mountain Flood Disaster Risk. Meteorological, 39, 325-330.

[18] Gemmer, M. (2004) Decision Support for Flood Risk Management at the YangtzeRiver by GIS/RS Based Flood Damage Estimation. Shaker, Giessen, 108-127.

[19] Su, B.D., Jiang, T., Guo, Y.Y., et al. (2005) Flood Risk Dynamic Simulation Model Based on GIS Raster Data and Its Application. Journal of Hohai University, 33, 370-374.

[20] Geomer (2003) Floodarea-Arcviewextension for Calculating Flooded Areas (User manual Version 2.4). Heidelberg.

[21] Zhang, R.Y., Xu, Z.H., You, L.J., et al. (2012) Spatial Distribution Characteristics and Risk Assessment of Tropical Cyclones in Fujian Province. Applied Meteorological Journal, 23, 672-682. 